\title{
Effect globalization on dentistry
}

\author{
Shaik Ali Hassan ${ }^{1}$, Sumit Bhateja ${ }^{2}$, Geetika Arora ${ }^{3}$, Francis Prathusha ${ }^{4}$ \\ ${ }^{1}$ Dental Surgeon, ${ }^{2} \mathrm{HOD},{ }^{3}$ Reader, ${ }^{4} \mathrm{MDS},{ }^{1}$ Dept of Dentistry, ${ }^{\mathbf{1} 4} \mathrm{Francis}$ Maxillofacial and Dental Clinic, India, ${ }^{2}$ Manav Rachna Dental \\ College, Haryana, India, ${ }^{3}$ Inderprastha Dental College and Hospital, Uttar Pradesh, India
}

*Corresponding Author: Shaik Ali Hassan

Email: alishaikhassan@gmail.com

\begin{abstract}
Globalization is a broad term that refers to the economic, social, technological, cultural, and political linkage driven by human migrations, international trade, the rapid movement capital and financial market integration across national borders. Globalization has had a significant impact on the operation and survival of the business and the world of education; education in dentistry has not been immune. In this review article we will tell ho globalization effects the dentistry.
\end{abstract}

Keywords: Globalization, Dentistry, DCI, CODA, Dental research, Dental products.

\section{Introduction}

Globalization is a vast term that refers to economic, social, technological, cultural and political interrelationships that are through human migration, international trade, rapid capital movement, and Integration of markets across national borders. $^{1}$ "The age of globalization" is fast becoming the preferred term for describing current times. As in the Cold War era, space Age and the roaring twenties are used to describe particular periods. From history; Globalization describes the political, economic and cultural atmosphere of today. $^{2}$ Globalization influences general wellbeing in an assortment of ways since it has released significant changes that have re-imagined how foundations at numerous levelscountry states, government offices, transnational partnerships, multilateral associations, non-administrative associations, open and private human services suppliers, network based and other fondness based associations, comm. solidarities, and family units work and communicate with each other. Globalization has significantly affected the activity and endurance of organizations around the world; the business of dentistry has not been resistant. The quick development of "dental the travel industry," where patients venture to the far corners of the planet for low-cost dental consideration, is one of the instances of the effect of globalization on the profession. ${ }^{3}$ While these models give point of view inside the act of dentistry, the effect of globalization on the advanced education division is as yet hidden. Until this point in time, dental training doesn't appear to have completely perceived nor exploited the advantages of globalization. Software engineering and Mechanical upheaval are getting space in our surrounding to an ever increasing extent often, which brings around two sort of social orders. ${ }^{4-6}$

Potential implications of globalization in dentistry

1. New discoveries could bring relief to the areas most in need.

2. In countries become more prosperous, such as India, Brazil, Russia and China, there is pent-up consumer demand for better oral health. To meet this demand, new dental schools will be launched.
3. There will be more schools and more students, thus covering a larger area of operation.

4. International accreditation and uniform global standard setting for dental education will become increasingly significant activity.

5. There will be a change in funding for dental research. National Institutes of Health (NIH) continues to be the main provider of funds in the United States. There will be more funds coming from international corporate sector and other countries growing research investment.

6. New models for labor allies teeth emerge and this will be particularly relevant in countries with high levels of dental and oral pathology in which there are fundamental flaws in their oral health services, and some places there are any services.

7. Technology will play a big role in promoting global dental education Web-based dental school and more reliance on e-learning.

8. Today many journals, research and marketing, and conference proceedings are available on the Internet. We can communicate with each other via e-mail regardless of time, distance or limits. This only further improve and develop. Disease knows no borders; also do not learn. The possibility to learn from each other will grow exponentially.

9. There will be more awareness and attention given to the majority of fellow citizens in our global village that did not have access to dental services and where the infrastructure is not just there to provide access to the appropriate educate health workers.

10. Global Issues dental education combines the real needs of society and a real chance to progress in the profession.

11. A re-formed IFDEA can become a major player in addressing issues of global oral health with the impact on public health priorities. ${ }^{7}$

\section{Effect on dental education}

Globalization of instruction is the inescapable outcome of a few variables present during just the previous a very long while: 
1. The development of universal travel during the recent years has incredibly expanded dental experts' energy about the requirement for global participation and, much more significantly, of the estimation of global involvement with improving the nature of training in their home foundations;

2. The expert and logical writing has become substantially more universal; generally major distributions support commitments from all over the world;

3. The broad communications, particularly TV, have welcomed imperative data on wellbeing status, quality of life, and financial elements from around the world legitimately into family rooms, making other nations and societies appear to be natural; and,

4. The presentation of the Internet has made data accessible momentarily all through the world. ${ }^{8}$

\section{Status of education in various countries ${ }^{9}$}

\section{USA}

The Commission on Dental Accreditation (CODA) is responsible for the accreditation of dental education and operates with participation from a number of agencies and associations such as the American Dental Association (ADA), American Dental Hygienists' Association (ADHA), and American Dental Education Association (ADEA). The accreditation process evaluates dental schools, dental hygiene and dental assisting programs, and postgraduate programs every seven years.

\section{United Kingdom}

The General Dental Council (GDC) is the regulatory authority which conducts site visits once every five years.

\section{India}

The Dental Council of India (DCI) is the body responsible for regulating the establishment of dental colleges and the profession of dentistry. There is no provision for the subsequent periodic accreditation of those colleges. The DCI is regulated and financed by the government.

\section{China}

Medical education in China is supervised and approved by the Ministry of Education of the People's Republic of China. The Ministry of Education strives for uniformity of educational programs as a cornerstone of quality and conducts the accreditation process for all dental schools in China. It is not clear from the literature or the ministry website whether there are provisions for subsequent periodic accreditation.

\section{Europe}

A government agency under the Ministry of Education is responsible for accreditation and is the same for all professional studies. The European accreditation cycle is usually five years. This process is similar in Union (EU) most EU countries, but there is no universal system of accreditation in Europe. Each country usually ensures quality independently, sometimes using a site visit and sometimes using external examiners.

\section{Globalization of dental research}

Answers for some worldwide oral medical problems will depend progressively on logical and mechanical information created through exploration. Chances to grow information depend in enormous measure on the accessibility of properly qualified logical ability to address required examination questions what's more, the accessibility of exploration cases. The two conditions loan themselves to more universal contribution. The United States oral science workforce is among the best on the planet, however has shortages in a number of basic territories, especially in clinical research limit (National Research Council, 1994 what's more, 2000). The United States populace encounters some oral ailments and conditions that are serious however are not common and, hence, give just a constrained examination base. For instance, head and neck tumors, and congenital fissure and congenital fissure exist in this nation, however there are higher occurrences in Southeast Asia and in Brazil. Uncommon irresistible maladies, for example, noma, have been seen in the US and in Western Europe, however are more pervasive in Africa.

Even questions about the optimal level of fluoride for humans take on international significance due to unique geography and dietary practices. ${ }^{10}$ Fortunately, all three factors lend themselves to international collaboration. Cooperation among nations will bring together scientists trained in epidemiology, dental informatics, health services research and other vital areas who are capable of addressing these research questions. ${ }^{11}$ If the financial burden is shared by multiple institutions and countries, the research has a much greater chance of being realized..$^{12,13}$

\section{Effect on dental products}

Worldwide normalization of the dental items that are accessible in overall markets could have a beneficial outcome for rehearsing dental specialists all through the world. At present, dental specialists don't have the affirmation that the items they purchase satisfy even negligible guidelines. ${ }^{14}$ This circumstance has accepted much more noteworthy significance as an ever increasing number of dental specialists are depending on the Internet to buy items from around the globe. Moral dental manufacturers bolster inflexible and steady worldwide principles. Such norms direct the turn of events and dissemination of their items, and guarantee their worthiness in the commercial center. Likewise, all inclusive norms could result in lower item costs, more noteworthy decision in results of better and reliable quality, trust in the evaluation of items, and upgraded security and wellbeing for our patients. ${ }^{15,16}$

\section{Conclusion}

Guaranteeing sufficient access to oral medicinal services benefits and improving the degree of oral wellbeing in creating nations are progressively significant worries of wellbeing strategy. Dental training should be occupied with these general wellbeing strategy discusses. A perfect way to deal with the globalization of dental instruction is for all nations to cooperate to recognize regular difficulties, share 
encounters, and pool scholarly assets. To discover the right harmony among advantages and expenses related with globalization, residents of all countries need to see how globalization works and the strategy decisions confronting them and their social orders.

\section{Source of Funding}

None.

\section{Conflict of Interest}

None.

\section{References}

1. Berry J. Globalization and its implications for dentistry. ADA News, April 2006.

At:www.ada.org/prof/resources/pubs/adanews/adanewsart icle. asp?articleid=1883. Accessed: March 7, 2008.

2. Rivas GJ, Becerra LC. The dentist profession in the globalization processes. ADM 2004;61(4): 150-4.

3. Donaldson ME, Cynthia C. Amyot G et al. Dental Education in a Flat World: Advocating for Increased Global Collaboration and Standardization. J Dent Educ. 2008;408-21.

4. Mahal AS, Shah N. Implications of the growth of dental education in India. J Dent Educ. 2006;70(8):884-91.

5. Friedland B, Valachovic RW. The regulation of dental licensing: the dark ages? Am J Law Med 1991;17(3):249-70.

6. Marklein MB. The incidental tourist. USA Today, July 28, 2005. At: http://usatoday.com/tr avel/news/2005-07-28- dentaltourism_x.htm.

7. Chambers DW, Gerrow JD. Manual for developing and formatting competency statements. J Dent Educ. 1994;58(5):361-6.8. "Brain drain in Africa".

8. Elliott-Smith S. Teledentistry: A new view on oral health care. Access, February 2007:8-15.
9. Dental Education in Europe. Towards convergence (The Dent Ed Thematic Network Project). Shanley D(ed). Budapest: Dental Press ktp. Publishers 2001.

10. Michael J. Till. The Future of Dentistry. The Am Dent Assoc. 2001.

11. Donaldson ME, Amyot CCG, Khajotia SS, Nattestad A, Norton NS, Zubiaurre LA et al. Dental Education in a Flat World: Advocating for Increased Global Collaboration and Standardization. J Dent Educ.2008;72(4):408-21.

12. Chambers DW, Gerrow JD. Manual for developing and formatting competency statements. J Dent Educ. 1994;58(5):361-6.

13. Lenburg C. The framework, concepts, and methods of the competency outcomes and performance assessment (COPA) model. Online J Issues Nurs 1999; Sept:4.

At:www.nursingworld.org/MainMenu Categoies/ ANAMarketplace/ANAPeriodicals/OJIN/ TableofContents/ Volume41999/No3Sep1999.aspx.

14. Ollila E. Global health priorities - Priorities of the wealthy? Global and Health. 2005;1(6).

15. Field M, ed. Dental education at the crossroads: challenges and change. A Report of the Institute of Medicine. Washington, DC: National Acad Press. 1995.

16. Shanley DB, Barna S, Gannon P, Kelly A, Teljeur C, Munck C et al. Undergraduate training in the European Union; convergence or divergence? Eur J Dent Educ. 1997:1(1):3543.

How to cite: Hassan SA, Bhateja S, Arora G, Prathusha F. Effect globalization on dentistry. J Manag Res Anal. 2020;7(3):101-3. 